УДК 327(73:55) «196/197»

Василь Гулай,

професор, доктор політичних наук,

завідувач кафедри міжнародної інформації,

Національний університет «Львівська політехніка»,

ORCID ID: 0000-0002-7609-7967

Vasyl.V.Hulai@LPNU.UA

\title{
Сергій Ніколаєв,
}

кандидат технічних наук, доцент кафедри міжнародної інформації, Національний університет «Львівська політехніка»,

ORCID ID: 0000-0001-8536-8725

Serhii.M.Nikolaiev@LPNU.UA

\section{Валерія Слшинова,}

студентка 4 курсу бакалаврату ОНП «Міжнародна інформація», Національний університет «Львівська політехніка»,

ORCID ID: 0000-0003-4219-9719

valeriia.yelshynova.mv.2017@1pnu.ua

DOI 10.29038/2524-2679-2020-02-276-293

\section{ДОСЛІДЖЕННЯ ІНВЕСТИЦІЙНОЇ ПРИВАБЛИВОСТІ В МІЖНАРОДНИХ ВІДНОСИНАХ НА ПРИКЛАДІ КРАЇН ІЗ ПЕРЕХІДНОЮ ЕКОНОМІКОЮ}

У вступі розкрито актуальність теми дослідження та сформульовано наукову проблему. Проведено аналіз основних публікацій $i$ досліджень. Сформульовано мету й поставлено основні дослідницькі завдання роботи. Описано методику дослідження системи міжнародних відносин та одного з явищ сфери міжнародних економічних відносин - інвестичійну привабливість. Основну частину статті становлять дослідження й опис категорії приватні іноземні інвестииії та їх роль, значення для країн із перехідною економікою. Світова практика неодноразово доводила доиільність використання прямих іноземних інвестицій як одного 3

(C) Гулай В., Ніколаєв С., Слиинова В., 2020 
ключових елементів економічного й сочіально-політичного розвитку держави. Країни-резиденти, котрі отримали фінансування від іноземних компаній, міжнародних інституиійних установ або ж країн, акумулювали изі активи задля подальшого покращзення виробничих потужностей, розвитку науково-технічної бази, погашення зовнішнього боргу тощзо. Ці дї прямо чи опосередковано позитивно вплинули на добробут країн. Особливу увагу звернуто на проблему взаємозалежності економічного зростання національної економіки та прямих іноземних інвестицій, щзо досі не втратила своєї актуальності, особливо для держав із перехідною економікою. Інвестииійна привабливість для останніх має фундаментальне значення під час формування порядку денного. Особи, котрі приймають рішення щзодо інвестування тих чи інших проєктів, мають свої системи координат. Однак уконтексті міжнародних відносин до головних критеріїв відносять інституційні, економічні, фінансові та соціально-політичні чинники. Для ширшого розкриття й дослідження проблеми змодельовано ситуацію, за якої один з інституційних інвесторів, а саме Свропейський банк реконструкиії та розвитку, застосовуючи багатокритеріальний порівняльний аналіз, обирає одну з трьох інвестиційно привабливих країн із перехідною економікою. Пошук рішення відбувався завдяки застосуванню математичних методів оцінювання й прикладних програм. Критерї, котрі порівнювалися, мали як якісний, так $і$ кількісний характер, а тому особа, яка приймає рішення, за иүєє̈ ситуаџї̈ покладалася на власне суб'єктивне бачення ситуащіï, за наявності знань та досвіду визначала їхню роль $i$ значимість, приймаючи тим самим оптимальне рішення в досліджуваній сфері. Важливо також $і$ те, щуо спочатку проведено обрахунки згідно з першою категорією даних - макроекономічні показники країн, далі - згідно з другою - дані економічної свободи. Вихідні результати, відповідно до двох перших обрахунків, відрізнялися та не привели до одностайного рімення. Оптимальний варіант знайдено лише після уніфікащї обох систем. На завершення зроблено аналіз переваг $і$ недоліків застосованого методу, надано рекомендащї для держави, яка отримала найменше значення. Розуміння та послідовне усунення негативних факторів, котрі зменшують інвестиційну привабливість, змічнять і покращзать міжнародне економічне становище. Отже, довгострокові капіталовкладення в нащіональні господарства є однією з форм реалізащії міжнародної політики. Інвестування двосторонній процес, а тому країні-резиденту потрібно зважати на рівень власної інвестиційної привабливості, максимізуючи позитивні якості та мінімізуючи негативні.

Ключові слова: система міжнародних відносин, міжнародні економічні відносини, інвестиційна привабливість, прямі іноземні інвестиції, країни з перехідною економікою. 


\section{1. ВСТУП}

Постановка проблеми. Міжнародні відносини комплексна та багатоелементна система, що поєднала в собі проблеми політичного, військового, технологічного, екологічного й економічного характеру. Сформовані протягом десятиліть міжнаціональні зв'язки в розрізі міжнародних економічних відносин визначають положення та місце держави в міжнародному співтоваристві, а також кількість і якість потоків факторів виробництва (капіталу, ресурсів). Рух капіталів (інвестицій) є важливою формою міжнародних взаємозв'язків. У сучасному глобалізовану світі інвестиційна привабливість стає одним із найпріорітетніших індикаторів залученості країн у систему світового господарства. Важливість міграції приватних іноземних інвестицій зумовлена тим, що залучення довгострокових капітальних вкладень в економіку країн покращує стан національного господарства останніх. Особливо критичного значення набуває питання інвестування в національні господарства компаніями-нерезидентами та (або) міжнародними інституційними одиницями (наприклад МВФ, ЄБРР, OЕСР тощо) у держави 3 перехідною економікою. Перехідна, або трансформаційна, економіка - це стан економіки в період зміни суспільно-економічних систем, переходу від однієї системи до іншої, більш ефективної, як основи стабільного добробуту населення [17].

Трансформація відбувається на більше ніж чотирьох рівнях, серед яких - інституційний, економічний, фінансовий і соціальнопсихологічний.

Згідно зі звітом Європейського банку реконструкції та розвитку станом на 2019 р. 37 країн світу все ще перебувають на транзитному шляху до ринково- орієнтовної моделі економіки [8]. Для держав, зокрема України, Польщі, Грузії, підвищення інвестиційної привабливості $\epsilon$ стратегічним завданням і стає основою для розв'язання соціальноекономічних проблем, які $є$ частиною суспільства протягом десятків років.

Аналіз останніх досліджень і публікацій. Українські дослідники I. Вербіцька, Г. Грицаєнко, М. Грицаєнко, Г. Глуха, Г. Коваль, О. Пирог, Н. Скоробогатова, С. Созінова та ін. досліджували природу поняття іноземних інвестицій, їхні переваги й недоліки, ознаки інвестиційної привабливості та роль залучення прямих іноземних інвестицій у країни, що мають трансформаційну економіку. Далі дослідження 
стосувалися безпосередньо взаємозалежності економічного зростання й інвестиційного клімату, водночас залученості прямих іноземних інвестицій. Українські вчені також висвітляють питання української інвестиційної привабливості, порівняно 3 державами, зокрема колишнього СРСР, надають рекомендації щодо збільшення притоку інвестицій у вітчизняну економіку.

Мета статті - аналіз системи міжнародних відносин, зокрема міжнародних економічних відносин, та однієї з форм міжнаціональної співпраці - прямих іноземних інвестицій - у контексті економічної вигоди як для інвестора, так і для країни, що отримує капіталовкладення; головних макро- та мікропоказників на прикладі України, Польщі, Грузії як держав із перехідною економікою в розрізі інвестиційної привабливості.

Досягнення поставленої мети вимагає виконання таких завдань:

1) дослідити поняття прямих іноземних інвестицій та їх вплив на економічний розвиток держав;

2) проаналізувати на прикладі країн із перехідною економікою ключові економічні характеристики, що впливають на інвестиційну привабливість;

3) визначити вплив інституційних, економічних, фінансових i соціально-політичних показників на місце та положення держав у міжнародному співтоваристві;

4) установити інвестиційно привабливу країну за допомогою методу аналізу ієрархій.

\section{2. МЕТОДИКА ДОСЛІДЖЕННЯ}

Методологічна основа дослідження грунтується насамперед на загальнонаукових методах: метод системного аналізу, який передбає синтез та аналіз фактичних даних, порівняння, моделювання. Аналіз і синтез означають дослідження природи та ролі міграції приватних іноземних інвестицій, їх впливу на економічний і соціально-політичний розвиток держав та зростання інвестиційної привабливості останніх. Порівняння країн із перехідною економікою, що грунтується на якісних і кількісних показниках. Змодельована ситуація в міжнародних відносинах у поєднанні з методом аналізу ієрархій дає змогу всебічно розглянути об'єкт дослідження та виконати поставлені завдання. Аналіз ієрархій це метод ієрархічного впорядкування альтернатив (варіантів рішення), iз яких складається завдання (проблема) і визначення критеріїв вибору 
альтернатив. Ідея методу полягає в попарному порівнянні скінченної кількості альтернатив.

\section{3. РЕЗУЛЬТАТИ ДОСЛІДЖЕННЯ}

Спираючись на світовий досвід, можемо стверджувати, що визначальною передумовою трансформаційних перетворень та економічного зростання країни є надходження й ефективне використання прямих іноземних інвестицій (далі - ПII) [1]. За визначенням експертів Міжнародного валютного фонду (МВФ) у 1977 р. та Організації економічного співробітництва та розвитку (ОЕСР) у 1983 р., «прямі іноземні інвестиції - це такі, що здійснюють за межами національних кордонів з метою розширення виробництва товарів і послуг, закупівлі товарів для імпорту в країну базування або експорту в треті країни. Їх характерними рисами $є$ те, що інвесторові належить управлінський контроль над підприємствами, і вони виступають у формі акціонерного капіталу і коротко- та довготермінових міжфірмових позик». Кінцева

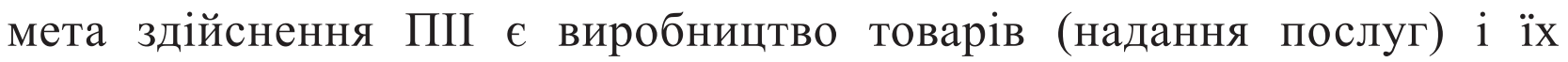
подальше переміщення між країнами. Акумуляція капіталу в середині однієї країни в довготривалій перспективі має низку істотних переваг перед іншими формами економічного співробітництва для останньої, а саме: ПII не стають тягарем зовнішнього боргу, а навпаки - сприяють його погашенню; імпорт прямих підприємницьких капіталів збільшує в країні виробничі потужності; ПІІ є джерелом нових технологій та передових методів управління й маркетингу, сприяють розвитку національної науково-дослідної бази; сприяють більш ефективній приватизації та реструктуризації економіки, створюють додаткові робочі місця, при цьому збільшуючи реальні доходи працівників; у країні збільшуються бюджетні надходження у вигляді податків на діяльність міжнародних спільних підприємств; імпорт ПІ стимулює конкуренцію й пов'язані 3 нею позитивні явища (підрив позицій місцевих монополій, зниження цін та підвищення якості продукції, що заміщує як імпорт, так і застарілі вироби місцевого виробництва); ПІІ забезпечують найбільш ефективну інтеграцію національної економіки у світову [8].

Водночас прямі приватні інвестиції мають і негативні наслідки. Виходячи 3 природи поняття інвестицій, зазначимо, що останні передбачають виконання підприємницької діяльності, а отже, вагома частка контролю над підприємством належить інституційній одиниці (інвестору). Така форма керування містить у собі потенційні загрози, ризики для певних держав. Головними проблемами для приймаючих 
країн при цьому є занадто велика роль міжнародних компаній в окремих сферах економіки, їх економічна сила, спроможність до маневрування в міжнародному просторі, як i обмеження ними національного суверенітету країн-реципієнтів ПІІ. Зокрема, мотивуючи відсутність товарів виробничого призначення на внутрішньому ринку, іноземні компанії можуть їх імпортувати зі своїх зарубіжних філіалів за трансфертними цінами, а останні, зазвичай, не відображають реальних умов торгівлі й значно розходяться з ринковими цінами [9].

До недоліків ПІІ із погляду економіки країни-об’єкта інвестування, також відносимо ризик усунення 3 ринку вітчизняних виробників $\mathrm{i}$ постачальників; сувору експлуатацію місцевих сировинних ресурсів; збільшення залежності країни від іноземного капіталу; постачання (збут) неякісних, недосконалих i морально застарілих ресурсів та активів; модифікацію структури економіки та їх пристосування до інтересів інвестора; погіршення платіжного балансу; деформацію культури підприємництва [9].

Однак світова практика на прикладі розвинутих держав неодноразово доводила свою ефективність і позитивний вплив на загальний добробут держав. Разом із тим особливо гостро постає питання залучення іноземних інвестицій у країни з перехідною економікою, а саме в групу держав, які перебувають у процесі реформування політичної та соціально-економічної структури, трансформації наявних тут раніше адміністративно-командних економічних систем у ринкову економіку [2].

Отже, для держав із перехідною економікою іноземні інвестиції відіграють безпосередню роль у процесі покращення національного господарства, упровадження інноваційних технологій, нарощування експортного потенціалу.

Інвестування насамперед пов'язане 3 прийняттям управлінських рішень та прогнозуванням можливих результатів особою, яка приймає рішення (далі - ОПР), або їх групою. Середовище, у якому оперує ОПР, $\epsilon$ складною системою взаємозалежних компонентів, детальний аналіз якої дає можливість зробити оптимальний вибір, кращий із наявних; засобу дій серед заданої множини альтернатив для досягнення поставленої мети. Цілком виправданою стане теза про те, що чим глибше ОПР вникає в цю складність, зіставляє можливі альтернативи, тим кращими будуть його прогнози або прийняті рішення.

Одним із методів, який розв'язує проблему складності аналізу численних альтернатив, є метод аналізу ієрархій (далі - MAI), запропонований у 1977 р. американським математиком Томасом Сааті [5]. 
Суть методу полягає в кількісному вираженні якісних суджень. Проблема структурується у вигляді ієрархії. Вершиною іiі зазвичай є глобальна мета, на наступному рівні наявні цілі, нижче - підцілі, потім - критерії, підкритерії; на нижньому рівні - альтернативи. Спочатку експерти генерують безліч припустимих альтернатив, серед яких потрібно провести вибір кращої альтернативи або впорядкувати всі елементи. Зазвичай на цьому етапі проводять розумне скорочення множини всіх можливих альтернатив або його кластеризацію у зв'язку з обмеженням методу на чисельність одночасно порівнюваних об'єктів.

Альтернативи також порівнюють за окремими критеріями. Засобом визначення коефіцієнтів значущості критеріїв та альтернатив $є$ попарне порівняння. Результат порівняння оцінюють за бальною шкалою (табл. 3). На основі таких порівнянь обчислюють коефіцієнти значущості критеріїв, оцінки альтернатив і дають спільну оцінку як зважену суму оцінок критеріїв. На якість порівнянь можуть впливати кваліфікація осіб, котрі приймають рішення, та (або) характерні особливості елементів ієрархії.

Інвестиційна діяльність $є$ однією з необхідних умов сталого зростання економіки, а також ефективного функціонування, конкурентоспроможності, розвитку більшості як підприємств, так і держав у цілому. Нині більшість підприємств не мають власних джерел фінансування капітальних укладень. Тому в цих умовах дедалі більшого значення набувають науково обгрунтовані розрахунки щодо оцінки економічної ефективності інвестиційних проєктів та їх відбору з низки попередньо опрацьованих альтернативних варіантів для фінансування та реалізації.

Одним із найефективніших інструментів дослідження, аналізу й прогнозування будь-якої економічної системи (явища, процесу) $\epsilon$ математичні методи та моделі й можливість їх реалізувати розрахунки автоматично, за допомогою прикладних програм.

\section{Програмні системи підтримки прийняття оптимальних рішень}

1. ExpertChoice - одне 3 найперших програмних забезпечень реалізації процесу аналітичної ієрархії (АНР), яке грунтується на прийнятті рішень із кількома критеріями. ExpertChoice, створений Т. Сааті та Е. Форманом у 1983 р., по сьогодні постачається компанією Expert Choice Inc [11].

Рішення програми поєднують інструменти спільної роботи й перевірені математичні прийоми, допомагає отримати найкраще рішення щодо досягнення мети. Програма дає змогу структурувати складну систему, вимірювати важливість конкуруючих цілей та альтернатив, синтезувати інформацію, експертизу й судження, проводити 


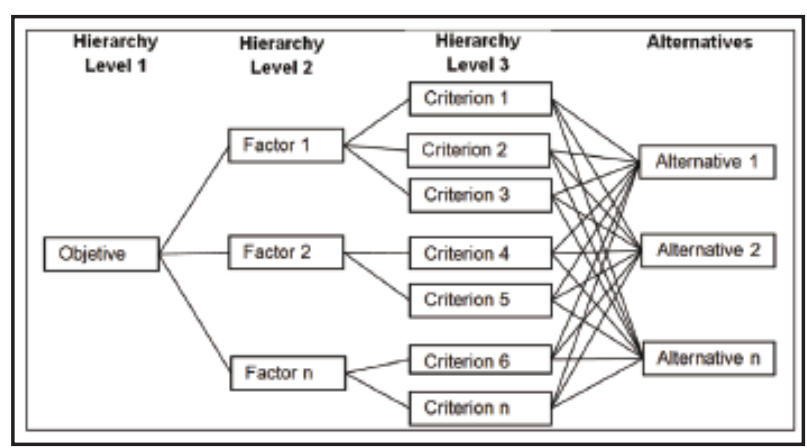

Рис. 1. Структура методу АНP

аналізи чутливості, чітко повідомляти для обміну результатами та інтератувати частини процесу прийняття рішення, коли це потрібно, виділити ресурси (за бажанням).

2. AHP Software (Transparent choice) - організація, що має на меті допомогти організаціям оцінити та зрозуміти, як їні проєкти в поточному стані й потенційно підтримують їхні стратегічні цілі. Це приводить до кращих рішень щодо проєктів і ресурсів, що дає їм змогу отримувати ефективні результати. Одним із програмних забезпечень

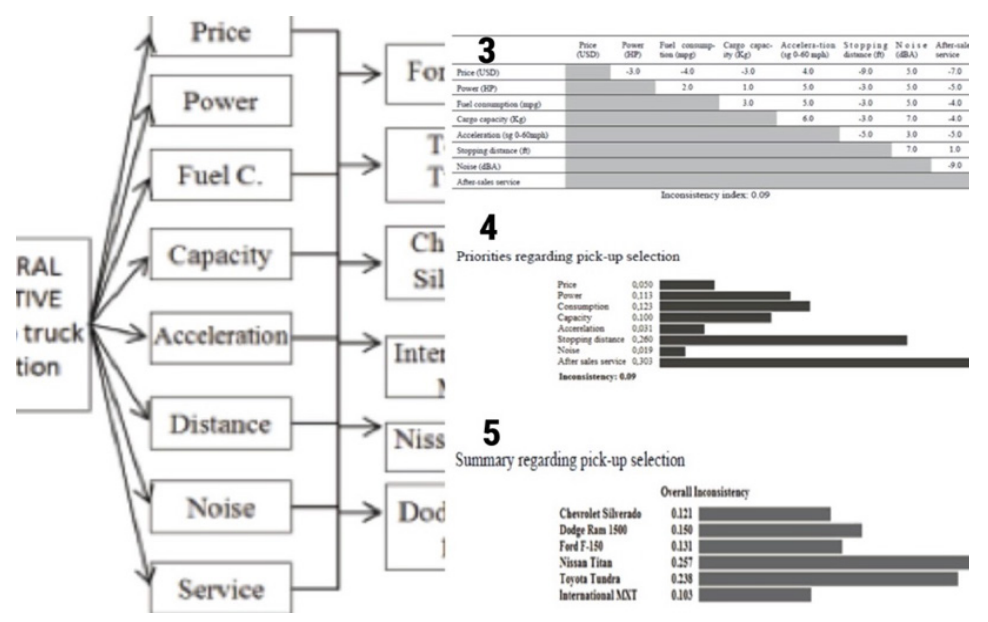

Рис. 2. Алгоритм методу АНР

компанії є AHP Software, що грунтується на математичних розрахунках методу аналізу ієрархій. Це уможливлює структурування свого рішення в покроковий процес.

3. MPRIORITY 1.0 - діалогова система «MPRIORITY 1.0» (My Priority) призначена для підтримки прийняття рішень у різних сферах людської діяльності. Програмна система грунтується на методі аналізу ієрархія (MAI). Основне його призначення - рішення слабоструктурованих завдань прийняття рішень. Систему «MPRIORITY» від своїх аналогів 
відрізняє діалоговий інтерфейс, адаптований під особливості MAI i сприйняття користувача. Програма містить діалогові засоби, що дають змогу отримувати найбільш повну інформацію про проведені попарних порівняння й усувати можливі неузгодженості в матрицях попарні порівнянь. Використання присутнього в програмній системі механізму шаблонів (шаблон - готова ієрархія для одного з завдань прийняття рішень), уможливлює адаптацію користування програми систему під сфери своєї діяльності [12].

Європейський банк реконструкції та розвитку (СБРР) належить до групи інституційних інвесторів [8]. Інституційні інвестори, на відміну від інших суб' єктів (наприклад транснаціональні компанії або приватні інвестори), мають ширші цілі, ніж максимізація прибутку. Вони сприяють реструктуризації підприємств, прискоренню трансформаційних процесів в економіці. Мета СБРР - сприяти побудові стійкої й відкритої ринкової економіки, шляхом інвестування коштів у проєкти, ведення діалогу 3 державними органами влади та наданням технічного сприяння.

Інвестиційна привабливість країни є тим індикатором, який свідчить про успішне функціонування політичних, соціальних, інституціональних, екологічних чинників, економічної політики на як макро-, так i на мікрорівнях. Як комплексний показник він зазнає впливу багатьох факторів прямої та опосередкованої дії [9]. 3 іншого боку, він і сам за своєю суттю впливає на економічний клімат. Безумовно, що кожен потенційний суб'єкт інвестиційної діяльності має власні критерії, вихідні позиції, на яких грунтується рішення щодо фінансування того чи іншого проєкту (держави). Однак, спираючись на критерії отримання фінансування від ЄБРР, можемо припустити, що основні макроекономічні показники та політично-соціальна ситуація в державах не залишаються поза увагою.

Критерії надання фінансування від СБРР [21]:

Для отримання фінансування від СБРР проєкт повинен відповідати таким критеріями:

- здійснюватися в країні операцій СБРР;

- припускати надання його спонсором великого внеску до статутного капіталу в грошовій або натуральній формі;

- слугувати інтересам вітчизняної економіки й сприяти розвитку приватного сектору;

- відповідати банківським й екологічним стандартам;

- мати хороші економічні перспективи.

Як бачимо, більшість із критеріїв оцінювання від СБРР за своєю 
суттю має якісний характер. Проте один із них - хороші економічні перспективи - можна перевести і в кількісну площину, проаналізувавши головні макроекономічні показники досліджуваних держав.

Для можливості надання більш чіткої альтернативи проаналізувати, зіставити отримані результати та обрати одну з найоптимальніших країн у контексті інвестиційної привабливості за критерії порівняння будуть прийняті дві системи з різними вихідними даними.

Перша - Звіт про розвиток країн із перехідною економікою ЄБРР «Better Governance, Better Economies» («Краще управління, кращі економіки»). У звіті представлено такі показники, які визначає банк та які слугують орієнтиром у визначенні привабливіших альтернатив: ріст ВВП; інфляція; фіскальний баланс, сальдо поточного рахунку; чисті ПІІ; зовнішній борг; кредити приватному сектору; валові резерви [23].

Друга - щорічний індекс економічної свободи, комбінований показник і супровідний рейтинг, що оцінює рівень економічної свободи в державах світу [16]. Індекс розраховуємо на базі 12 факторів, згрупованих у чотири категорії: верховенство права (права власності, ефективність судочинства й цілісність уряду); рівень утручання уряду (податковий тягар, державні витрати та фіскальне здоров'я); ефективність регулювання (свобода бізнесу, свобода праці й монетарна свобода); відкритість ринку (свобода торгівлі, свобода інвестування та фінансова свобода) [22].

Аналіз проблеми дослідження. Припускаємо, що інвестору (СБРР) запропоновано один проєкт, інвестування та реалізація якого мають відбутися в одній із трьох запропонованих держав - Україна, Польща, Грузія. Усім трьом країнам притаманна економіка перехідного типу, а тому додатковий капітал для них є вкрай необхідним для покращення добробуту громадян.

Для прийняття остаточного рішення, а саме визначення однієї 3 трьох держав, у контексті інвестиційної привабливості обрано дві вищезазначені системи координат, із яких і відібрані критерії для подальшого оцінювання.

Отже, за розрахунками, що грунтуються на макроекономічних показниках держави, Польща $є$ оптимальним варіантом щодо інвестиційної привабливості для потенційних капітальних вкладень.

\section{Рімення 2}

Рішення 2 (рис. 4) обраховували на основі вказаних 12 критеріїв (табл. 11). Згідно з попередніми судженнями та пріоритетами, отримано 


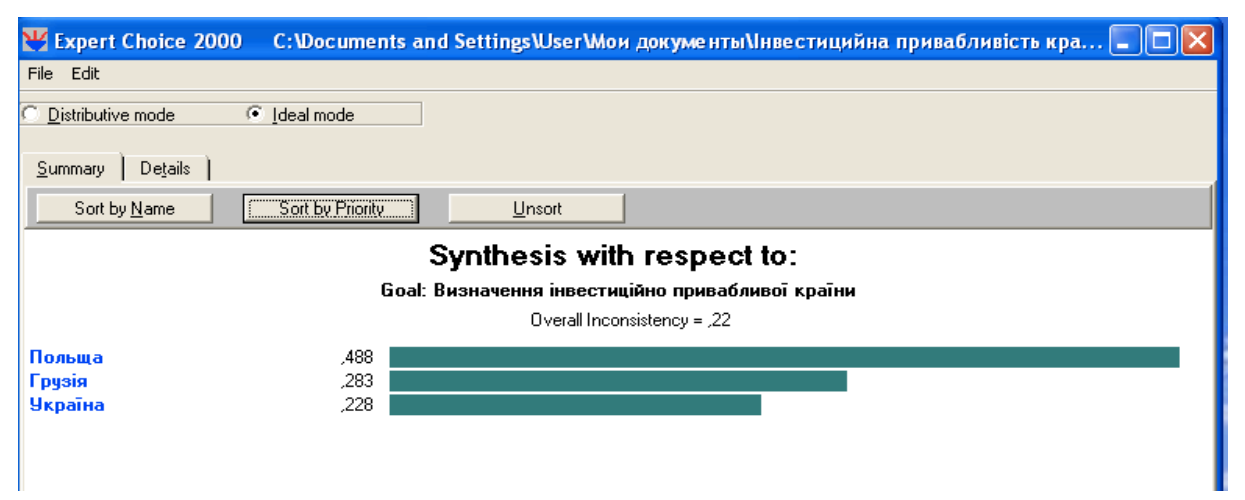

\section{Рис. 3. Розв'язання проблеми на підставі} макроекономічних показників

такі результати. Альтернатива 3, що відповідає країні Грузія, отримала найбільше значення компонентів вектора глобальних пріоритетів - 0,523. Для цієї країни найвищі пріоритети вектора альтернатив мають критерії «Верховенство права», «Рівень втручання уряду» і «Відкритість ринку».

\section{Рішення 3}

Під час пошуку рішення, що грунтувалося на двох системах із різними вихідними даними, виникла потреба в ще одному перерахунку, оскільки отримано неоднакові дані. Згідно з рішенням 1, інвестиційно

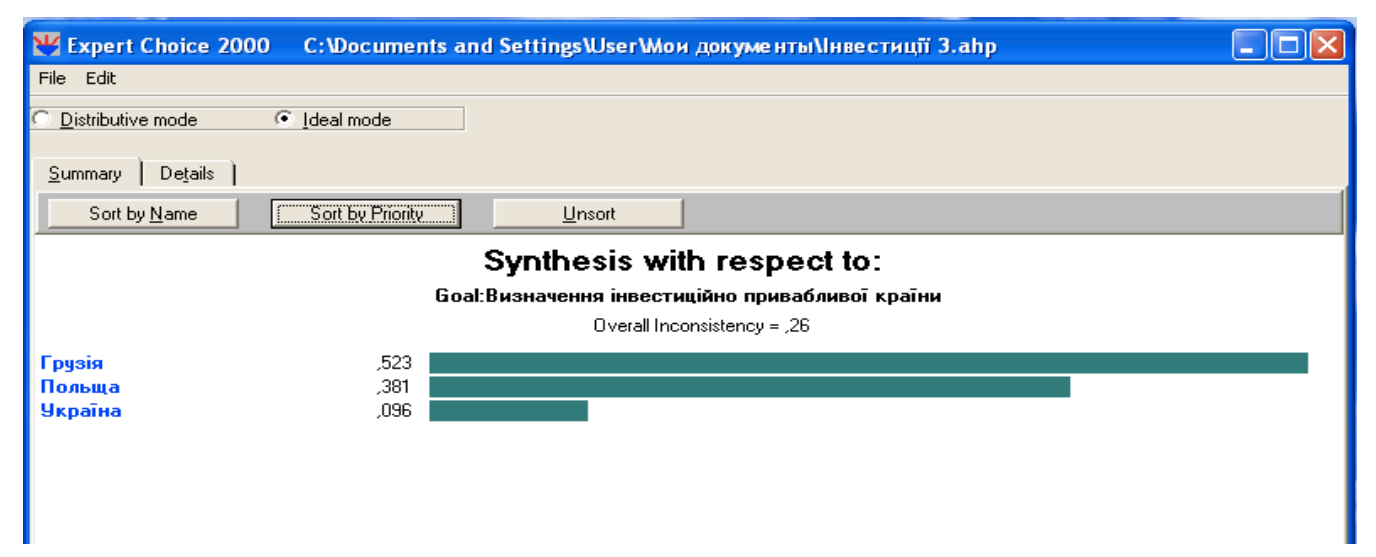

Рис. 4. Рімення на підставі Індексу

привабливою країною є Польща, згідно з рішенням 2 - Грузія. Аби отримати кінцевий результат й обрати все ж таки одну країну для потенційного інвестування, прийнято рішення інтегрувати дві системи в одну. Зроблено перерахунки, а саме попарне порівняння, формування суджень і визначення пріоритетів для кожного з 20 критеріїв. Найбільше значення отримала друга альтернатива - Польща із сумарним результатом 0,504. Отже, ця країна є оптимальною під час вибору. Різниця в результатах між двома альтернативами становить 0,008 . 


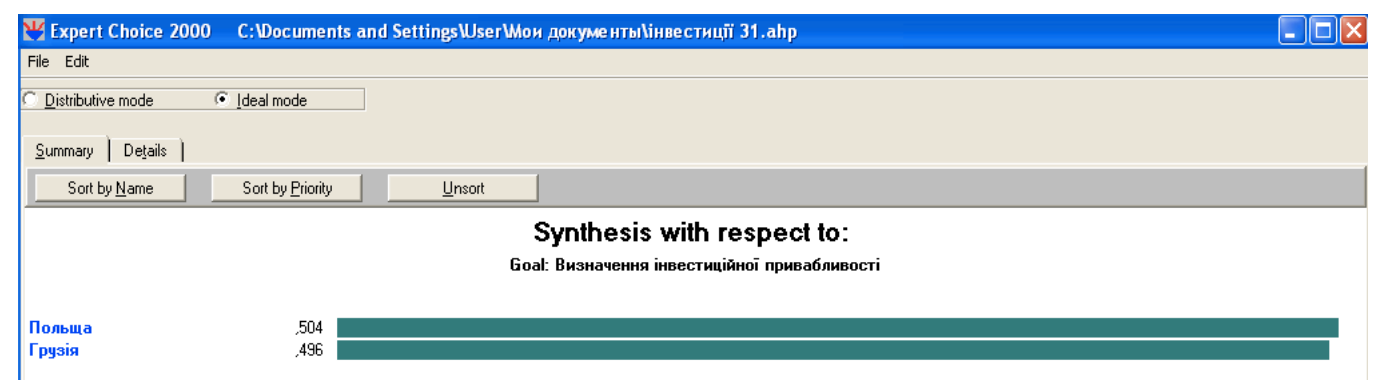

Рис. 5. Розв'язання проблеми на підставі інтегральних показників

Проведений порівняльний аналіз і застосування методу аналізу ієрархій під час визначення інвестиційно привабливої країни з перехідною економікою має такі переваги та недоліки: переваги - можливість адаптації показників і факторів для потреб інвесторів; змога здійснити апріорне визначення й ранжування за заданим критерієм найбільш істотних факторів; можливість провести аналіз складних систем (економічна й політичносоціальна ситуація в країнах); програми автоматичного розрахунку «Expert Choice» легко та швидко дають можливість знайти оптимальне розв'язання проблеми; можливість підвищити ефективність математико-статистичних та інших формальних методів за рахунок більш точного визначення й оцінювання якісних параметрів. До недоліків варто віднести суб'єктивність оцінки, залежність висновків від позиції осіб, котрі приймають рішення; велика кількість інформації; неможливість повного опису невизначеності системи переваг осіб, які приймають рішення, і наявність конфліктуючих систем переваг; у рамках методу аналізу інколи немає засобів для перевірки достовірності даних або ж вони як економічні показники динамічні, а відтак рішення можуть прийматися на основі неактуальних показників - це важливий недолік, що інколи частково обмежує можливості застосування методу.

Виходячи 3 проведеного аналізу та розрахунків, Україна жодного разу не отримала пріоритетної переваги над іншими альтернативами. За умови, що потенційний інвестор спиратиметься на вищезгадані системи даних, разом з оцінкою потенційної прибутковості вкладень та своїми уявленнями про ризики, маємо зазначити й рекомендації щодо покращення інвестиційного клімату в Україні як державі з перехідною економікою. Першочерговим $є$ досягнення цілісності уряду шляхом пошуку консенсусу між різноманітними політичними партіями 3 приводу розв'язання загальнонаціональних проблем виходу України 3 
економічної кризи та поліпшення ситуації в зоні АТО. Не менш важливим $€$ також [24] визначення чітких пріоритетів у зовнішній політиці України, необхідна цілеспрямована орієнтація на створення зони вільної торгівлі з $\mathrm{CC}$; подолання інфляційних коливань; упровадження економічного механізму страхування ризиків для іноземних інвесторів; забезпечення стабільності законодавства у сфері інвестування й оподаткування, удосконалення Податкового та Кримінально-процесуального кодексів; усунення технічних бар'єрів у процесі відшкодування ПДВ і митного оформлення товарів, забезпечення пільгового податкового режиму під час здійснення великих капіталовкладень в економіку України; створення системи виконання пакета законів щодо ліквідації корупції, зменшення адміністративного тиску на бізнес; проведення антимонопольних заходів і забезпечення внутрішнього конкурентного середовища для розвитку інвестиційної діяльності, покарання за їх порушення; розвиток системи державних гарантій, які надаються інвестору в пріоритетних для України напрямах інвестування; активізація заходів, щодо формування позитивного іміджу України..

\section{4. ВИСНОВКИ ТА ПЕРСПЕКТИВИ ПОДАЛЬШИХ ДОСЛІДЖЕНЬ}

Отже, у статті досліджено інвестиційну привабливість на прикладі міжнародних інвестицій, зроблених резидентом в одній країні 3 метою реалізації своєї довготермінової зацікавленості в проєкті, що є резидентом країни, іншої ніж держава місцезнаходження інвестора. Світова практика доводить, що основним джерелом стабільного розвитку країни є залучення зовнішніх капіталовкладень. Інвестиційне забезпечення є одним із ключових факторів розвитку національного господарства для держав, котрі розвиваються або перебувають у трансформаційному стані переходу від командно-адміністративної до ринкової системи економіки. ПІІ дуже важливі в цілому не лише через те, що вони приносять украй необхідний додатковий капітал та перспективне збільшення бюджету, але й тому, що забезпечують передачу сучасних технологій та ноу-хау, одночасно відкривають нові можливості для експорту й доступу до міжнародних ринків. Водночас за допомогою іноземних капіталовкладень зростає підприємницька діяльність, створюються нові робочі місця, відбувається притік іноземної валюти.

Однак за своєю суттю інвестиції передбачають отримання прибутку в довготривалій перспективі, а тому країна-реципієнт, із погляду 
потенційного інвестора, повинна мати стабільне політичне, економічне, фінансове й соціально-психологічне середовища. Ці фактори формують інвестиційну привабливість. Проаналізувавши економічні характеристики країн 12 економічних свобод на прикладі України, Польщі та Грузії, можемо стверджувати, що без верховенства права, адекватного й ефективного рівнів утручання уряду, регулювання бізнесу, монетарної політики, відкриття ринку, розраховувати на покращення макроекономічної ситуації складно, адже останнє є вихідним продуктом державного регулювання.

Методом аналізу ієрархії визначено інвестиційно привабливу країну. Польща отримала найбільше значення компонентів вектора глобальних пріоритетів - 0,504. Для цієї держави характерні високі показники, серед яких - такі критерії, як грошова свобода, свобода інвестицій, показник фіскального здоров’я. Також країна має найліпші макроекономічні показники.

\section{СПИСОК ВИКОРИСТАНИХ ДЖЕРЕЛ}

1. Свистун, Л. А., Мороховець, І. О. (2017). Перспективи іноземного інвестування в економіку України у контексті загроз іiі економічній безпеці. Глобальні та національні проблеми економіки, вип. 18, 483-489. URL: http://Global-National.In.Ua/ Archive/18-2017/92.Pdf

2. Козик, В. В., Панкова, А. Л., Даниленко, Н. Б. (2008). Міжнародні економічні відносини. Київ: Знання, 406 с. URL: http://Www.Info-Library.Com.Ua/Books-Text-4466. $\mathrm{Html}$

3. Трунова, В. О. (2013). Застосування методу Сааті при прийнятті управлінських рішень. Вісник Чернігівського національного педагогічного університету. Педагогічні науки.

4. Кульчицька, Х. Б., Предко, Л. С. (2018). Застосування методу аналізу ієрархій при виборі проекту в поліграфії. Поліграфія і видавнича справа, 1, 51-60. URL: http:// Nbuv.Gov.Ua/UJRN/Pivs_2018_1_7

5. Бадюл, М. Г., Крамаренко, В. А. (2013). Застосування методу аналізу ієрархій у проектуванні та будівництві. Будівництво, матеріалознавство, машинобудування. Дніпропетровськ, вип. 70, с. 27-35.

6. Саати, Т. (1993). Принятие решений. метод анализа иерархий/пер. с англ. Р. Г. Вачнадзе. Москва: Радио и связь, 278 с.

7. Тесля, С. М. (2009). Прямі іноземні інвестиції як економічна категорія, їх суть та класифікація. Науковий вісник НЛТУ Украӥни, 19, 131-138.

8. Федоренко, В. Г., Проценко, Т. О., Солдатенко, В. В., Степанов, Д. В. (2004). Економічні та організаційно-правові аспекти іноземних інвестицій в Україні: монографія. Ірпінь: Нац. академія ДПС України, 398 с.

9. Вербіцька, I. I. Інвестиційна привабливість України: проблеми та перспективи. URL: http://Global-National.In.Ua/Archive/22-2018/30.Pdf 
10. Zapata Cortes, J. Decision Support System Implementation for vehicle selection in a Colombian Shipyard URL: http://Www.Scielo.Org.Co/Scielo.Php?Script=Sci_Arttext\&Pi $\mathrm{d}=\mathrm{S} 0012-73532012000300021$

11. Программные системы поддержки принятия оптимальных решений. URL: http:/Www.Tomakechoice.Com/Mpriority.Html

12. Better Governance, Better Economies. EBRD. 2019. C. 17-20, 13-14, 19-21. URL: https:/Www.Ebrd.Com/News/Events/Better-Governance-Better-Economies.Html

13. Романенко, Є. О. Рейтинг індексу економічної свободи України. URL: http:// Www.Kbuapa.Kharkov.Ua/E-Book/Conf/2017-3/Doc/1/01.Pdf

14. Сірко, А. В. (2014). Економічна теорія. Політекономія: навч. посіб. Київ: ЦУЛ, $416 \mathrm{c}$.

15. Current Account (\% Of GDP). URL: https://Www.Focus-Economics.Com/Economic-Indicator/Current-Accountbalance\#: :Text=When $\% 20 \mathrm{a} \% 20$ country's $\% 20$ current $\% 20 \mathrm{ac}-$ count $\% 20$ balance $\% 20$ is $\% 20$ negative $\% 20$ (Also $\% 20 \mathrm{known}$, Country's $\% 201$ evel $\% 20$ of $\% 20$ international $\% 20$ competitiveness.

16. Прямі іноземні інвестиції. URL: https://Index.Minfin.Com.Ua/Ua/Economy/ Fdi/2018/

17. Список країн за зовнішнім боргом. URL: https://Uk.Wikipedia.Org/Wiki/ Список_Країн_За_Зовнішнім_Боргом

18. Валютні резерви. URLE: https://Uk.Wikipedia.Org/Wiki/Валютні_Резерви

19. Міжнародний кредит. URL: https://Uk.Wikipedia.Org/Wiki/Мiжнародний_ Кредит\#Зовнішній_Борг_України

20. Финансирование с участием ЕБРP, 2013. URL: https://Www.Ebrd.Com/Downloads/Research/Factsheets/Guider.Pdf

21. Index of economic freedom (2020). T. Miller, A. Kim, J. Roberts, P. Tyrrell. Washington: The Heritage Foundation, $524 \mathrm{c}$.

22. Transition Report 2019-20. URL: https://2019.Tr-Ebrd.Com/

\section{STUDIES OF INVESTMENT ATTRACTIVENESS IN INTERNATIONAL RELATIONS IN THE CASE OF COUNTRIES WITH ECONOMIES IN TRANSITION}

The introduction reveals the relevance of the research topic and formulates the scientific problem. The main publications and studies are analyzed. The goal was formulated and the main research tasks of the work were set. The methods of research of the system of international relations and one of the phenomena of international economic relations - investment attractiveness - are described. The main part of the article presents the research and description of the category of private foreign investments and their role and significance for the countries with transition economies. The international practice has repeatedly proved the expediency of using direct foreign investments as one of the key elements of economic and socio-political development of a state. Resident countries that have received funding from foreign companies, international institutional insti- 
tutions or countries have accumulated these assets in order to further improve their production capacities, develop their scientific and technological base, repay their foreign debt, and so on. These actions have had a direct or indirect positive impact on the welfare of countries. Particular attention is paid to the problem of interdependence of economic growth of national economy and foreign direct investment, has not lost its relevance, especially for countries with economies in transition. The investment attractiveness of the latter is fundamental in setting the agenda. Decision-makers on investment of this or that project have their own systems of coordinates. However, in the context of international relations the main criteria include institutional, economic, financial and socio-political factors. For wider disclosure and research of the problem, a situation was simulated in which one of the institutional investors, the European Bank for Reconstruction and Development, selected one of the three investment-attractive countries with economies in transition using a multi-criteria comparative analysis. The solution was found through the use of mathematical evaluation methods and applications. The criteria were compared both qualitatively and quantitatively, and therefore, the decision-maker in this case was entrusted with his or her own subjective vision of the situation, determining their role and significance, if knowledge and experience were available, thus resulting in an optimal solution in the field under study. It is also important that first calculations were made on the first category of data-macroeconomic indicators of countries, and then on the second category - indicators of economic freedom. Output results from the first two calculations differed and did not provide a unanimous decision. The optimal variant was found only after unification of both systems. In conclusion, the authors analyze the advantages and disadvantages of the method used and provide recommendations for the country that received the lowest value. Understanding and consistently addressing the negative factors that reduce investment attractiveness will strengthen and improve the international economic situation. Thus, long-term investment in national economies is a form of international policy implementation. Investment is a two-way process, and therefore, the resident country should also take into account the level of its own investment attractiveness, maximizing its advantages and minimizing negative ones.

Key words: system of international relations, international economic relations, investment attractiveness, foreign direct investment, countries with economies in transition.

\section{REFERENCES}

1. Svistun, L. A., Morokhovets, I. A. (2017). Perspectives of investment instruction in the economic security of Ukraine in context, 18, 483-489. http://Global-National.In.Ua/Archive/18-2017/92.Pdf

2. Kozik, V. V., Pankova, L. A., Danilenko, N. B. (2008). International economic relations Kiev: Znannia, 406. http://Www.Info-Library.Com.Ua/Books-Text-4466.Html 
3. Trunova, O. V. (2013). Application of the saati method in making managerial decisions. Vestnik of Chernigov National Pedagogical University. Pedagogical Sciences.

4. Kulchitskaya, H. B., Predko, L. S. (2018). Application of the method of analysis of hierarchies when choosing a project in Polygraphy, 1, 51-60. Available: http://Nbuv. Gov.Ua/UJRN/Pivs_2018_1_7

5. Badiul, M. G., Kramarenko, V. A. (2013). Application of the method of hierarchy analysis in design and construction. Construction, material science, mechanical engineering. Dnepropetrovsk, 70, 27-35.

6. Saati, T. (1993). Decision making the method of analysis of hierarchies/per. from English R. G. Vachnadze. Moscow: Radio And Communication, 278.

7. Teslya, S. M. (2009). The first investments as the economic category. The future and classification/Scientific Bulletin of NLTU of Ukraine, 19, 131-138.

8. Fedorenko, V., Protsenko, T. A., Soldatenko, V. V., Stepanov D. V. (2004). Economic and organizational-legal aspects of foreign investments in Ukraine: Monograph. Irpen: National Academy of State Tax Service Of Ukraine, 398.

9. Verbitsky, I. (2008). Investment in Ukraine: probles and perspectives. http://GlobalNational.In.Ua/Archive/22-2018/30.Pdf

10. Zapata Cortes, J. Decision Support System Implementation For Vehicle Selection In A Colombian Shipyard. http://Www.Scielo.Org.Co/Scielo.Php?Script=Sci_Arttext\&Pid $=$ S0012-73532012000300021

11. Software systems to support optimal decision making. http://Www.Tomakechoice. Com/Mpriority.Html

12. Better Governance, Better Economies. EBRD, 2019, 17-20, 13-14, 19-21. https:// Www.Ebrd.Com/News/Events/Better-Governance-Better-Economies.Html

13. Romanenko, E. A. (2017). Reiting index of economic freedom Ukraine. http:// Www.Kbuapa.Kharkov.Ua/E-Book/Conf/2017-3/Doc /1/01.Pdf

14. Sirko, A. V. (2014). Economic theory. Political economy: Training manual. Kiev: TSUL, 416.

15. Current Account (\% Of GDP). https://Www.Focus-Economics.Com/EconomicIndicator/Current-Accountbalance\#: :Text $=$ When $\% 20 \mathrm{a} \% 20$ country's $\% 20$ current $\% 20 \mathrm{ac}-$ count $\% 20$ balance $\% 20$ is $\% 20$ negative $\% 20$ (Also\%20,Country's\%20Level\%20of\%20international $\%$ 20competitiveness

16. Foreign direct investment. https://Index.Minfin.Com.Ua/Ua/Economy/Fdi/2018/

17. List of countries by foreign debt. https:/Uk.Wikipedia.Org/Wiki/Список_Країн За_Зовнішнім_Боргом

18. Currency reserves. https://Uk.Wikipedia.Org/Wiki/Валютні_Резерви.

19. International credit. https://Uk.Wikipedia.Org/Wiki/Мiжнародний_ Кредит\#Зовнішній_Борг_України

20. Financing with EBRD participation (2013). https://Www.Ebrd.Com/Downloads/ Research/Factsheets/Guider.Pdf

21. Miller, T., Kim, A., Roberts, J., Tyrrell, P. (2020). Index of economic freedom 2020. Washington: The Heritage Foundation, 524 p.

22. Transition Report (2019-20). https://2019.Tr-Ebrd.Com/ 
УДК 327.7-027.541(478:4/.5)(091)

Нарміна Мамішова,

аспірантка спеціальності «Міжнародні відносини, суспільні

комунікації та регіональні студії»,

Інститут міжнародних відносин,

Київський національний університет імені Т. Г. Шевченка,

narminamamishova@gmail.com

DOI 10.29038/2524-2679-2020-02-293

\section{УЧАСТЬ РЕСПУБЛІКИ МОЛДОВА В ОРГАНІЗАЦІї ЗА ДЕМОКРАТІЮ ТА ЕКОНОМІЧНИЙ РОЗВИТОК (ОДЕР-ГУАМ): ВІД ПРЕЗИДЕНТСТВА П. ЛУЧИНСЬКИ ДО ПРЕЗИДЕНТСТВА М. САНДУ}

Організаиія за демократію та економічний розвиток ОДЕР-ГУАМ була створена понад два десятиліття тому як платформа дружньої співпраці між кількома пострадянськими краӥнами, прихильними до євроатлантизму. У 2006 р. групування перетворено на повноцінну міжнародну організацію, яка об'єднала Грузію, Украӥну, Азербайджан та Молдову. На жаль, вважається, що організачії так $і$ не вдалося перетворитися на потужну платформу політичної координації та багатовекторного співробітництва для держав-членів. Одним із факторів вилучення організаиії з "великої гри» залишається амбівалентність внутрішньополітичних настроїв у країнахучаснииях, що ставить в залежність характер членства в ОДЕР-ГУАМ від лідерів, які перебуваються при владі в тій чи іншій країні. Значною мірою така тендениія стосується Республіки Молдова, яка, з огляду на нестабільну внутрішньополітичну кон'юнктуру, досі не реалізувала свій національний інтерес щодо членства в ОДЕР-ГУАМ, залишаючись осторонь інтеграційного процесу в організаиії та поза ї̈ амбітними міжнародними проєктами, у тому числі в галузі енергетики та транспорту із залученням територій країн «четвірки».

Незважаючи на геостратегічну роль, яку відграє співробітництво в рамках ОДЕР-ГУАМ у питаннях європейських та євроатлантичних прагнень новоутворених пострадянських республік, стримування політикоекономічної експансї євразійських інтеграційних проєктів, спільності загроз актуальних та заморожених збройних конфліктів у регіоні ОДЕРГУАМ, перспективності торговельно-економічних проєктів, а також актуальності забезпечення європейської енергетичної безпеки, організа- 